Vol. 8, No. 1, 2021

https://doi.org/10.23939/eem2021.01.059

UDC 657.421.3

JEL Classification Code: M 41

O. Lemishovska

Lviv Polytechnic National University, Ukraine, PhD, Associate Professor

E-mail: olesia.s.lemishovska@lpnu.ua

ORCID: 0000-0002-5695-0924

I. Mazur

Lviv Polytechnic National University, Ukraine, bachelor

E-mail: irynkamaz@gmail.com.

\title{
THEORETICAL AND METHODOLOGICAL PRINCIPLES FOR ACCOUNTING REFLECTON OF GOODWILL: DIALECTICS OF DEVELOPMENT AND DIRECTIONS OF IMPROVEMENT
}

\begin{abstract}
The rapid development of market relations, Ukraine's integration into the world economic space, encourage companies, in order to achieve competitive advantages, to explore new ways of capitalization. At the same time, the operations of purchase, sale, merger or acquisition of companies, the value of which directly depends on intellectual capital, are becoming more common. The difference in the assessment of market and book value of intellectual capital leads to a special economic and accounting category - goodwill.Despite the prospects of using such a component of assets as goodwill, today there are still a number of theoretical and practical problems, for example: problem of unambiguous understanding and interpretation of the essence of goodwill, methods of its valuation, and the practice of reflecting it in accounting and reporting by domestic enterprises.

The study addresses issues related to establishing the nature of goodwill, its content as an intangible economic resource of the enterprise and the component of the value of capital and the problem object of accounting.The purpose of the work is to reveal the economic essence of goodwill as an object of accounting, to conduct a critical analysis of the current standardization of goodwill accounting, to generalize and systematize of existing problems in the formation of accounting information about this object. The task of this study is to formulate separate proposals for improving methodological approaches to accounting for goodwill, which are obtained on the basis of examined
\end{abstract}

legislative and research sources of information. The scientific novelty lies in the substantiation of the accounting category of goodwill as a subjective value and an objectively existing resource, which should be actually reflected in accounting and reporting.

Key words: accounting, enterprise, goodwill, internally generated goodwill, intangible assets, capital, business value.

Formulation of the problem. The dynamic development of market relations in the global space, the integration of Ukrainian enterprises into world economic relations, including investment, necessitate the demonstration of their competitive advantages. Modern market conditions encourage companies of any national economy to find ways to capitalize on their business.

The importance of this criterion is that the operations of purchase, sale, merger or acquisition of companies, the value of which directly depends on their available capital of intangible nature and business reputation in the market, expressed in the category of "goodwill" (acquired and created by the enterprise) are becoming more common.

At the same time, today there are a number of theoretical and practical problems regarding the method of goodwill valuation for accounting purposes, as well as the generally accepted practice 
of reflecting this object in public reporting by enterprises.

The reflection in accounting and the presentation in one way or another of public information about goodwill as an economic resource of the intangible type during the evolution of this system has always been and remains to be the subject of discussion. The dual economic and legal nature of this economic category gives rise in accounting practice to different approaches to accounting for this object. Throughout the history of the development of accounting theory and practical accounting, unified approaches to its recognition, evaluation and agreed methods of reflection by the accounting system have not been achieved. This applies to both purchased and internally generated goodwill. This type of resources has a dual economic nature - they form a value comparable only to a particular enterprise (for example, a trademark) which, at the same time, is not directly commensurate with the costs incurred for its formation (primarily for goodwill created by the enterprise). At the same time, a significant part of the components of goodwill, as well as this economic category in general, cannot be identified with the help of traditional accounting tools. This makes it difficult to reflect it in the public reporting of the enterprise for the presentation of the book value of the business, makes it impossible to use accounting information in the processes of market valuation of economic entities.

In modern practice, the basic principles of estimating the market value of goodwill and other components of intellectual capital are focused on the use of expert assessments projected on the hypotheses of efficient market (Efficient Market Hypothesis) and the model of capital and asset valuation (Capital Asset Pricing model). In these models, data on the value of goodwill and other intangible economic resources are formed on the basis of subjective estimates that provide a fairly reliable expression of the fair value of assets and liabilities [1]. However, in modern accounting standardization, as the famous scientist Baruch L. concludes, "many estimates, such as the fair value of non-trading (non-market) assets, and especially goodwill, are often not better than simple assumptions and have a tendency to manipulate" [2].
Fluctuations in the share price of wellknown companies on stock exchanges, which have systematically occurred over a long period, many analysts have attributed to the incorrect assessment (usually inflated) of goodwill and other intangible components of the market value of modern companies. The operation of well-known and socially significant companies in the global pandemic COVID 19 further confirmed the fact of overestimation of goodwill in most of them.

Based on the above and a number of other problematic aspects it becomes relevant the question of developing and improving accounting methods to more objectively reflect the entire intangible potential of the enterprise, expressed by the category of goodwill: "today the problem of objective reflection of goodwill as an accounting and economic object" [3, p. 1165].

\section{Analysis of recent research and publications}

In its specialized report for 2019, "Accountancy Europe" indicates that current accounting methods in many cases do not take into account internally generated intangible assets, which have become a major component of the market value of companies [4, p. 4].

Assessing the possibility of developing accounting methods based on existing standardization, a well-known researcher in the field of intangible assets and goodwill as components of capital of modern companies Marr W. concludes that the search for "objective approach to valuation of intangible assets creates huge problems, thus objective accounting for intangible assets is either quite complex or almost impossible" [5, p. 172].

Modern studies use different positions to improve the accounting of intangible assets, but also offers a reference to the developments of the past. This applies both to the view of the content of economic matter of certain types of economic resources, and the evolution of accounting techniques in general. For example, I. M. Nazarenko argues that "for an in-depth understanding of the accounting interpretation of the studied category is important retrospective analysis of the development of categorical-conceptual apparatus" [6, p. 135]. 
Formulation of research goal.

The purpose of the study is to reveal the content of "goodwill" as an accounting and economic category, to conduct a critical analysis of existing principles, approaches and regulations to reflect these objects in the accounting system, to generalize and systematize scientific achievements on approaches to goodwill accounting during the evolution of accounting.

Specific tasks include:

- to find out the essence and components of goodwill, its economic content in the acquisition and creation directly by the enterprise;

- generalize approaches and methods of goodwill valuation;

- to analyze the international and domestic practice of reflecting goodwill in the accounting system, to identify the main problems;

- formulate proposals for improving certain aspects of accounting methods of goodwill accounting.

Scientific novelty: the theoretical component of the study substantiates the need to change the method of accounting for goodwill, the practical orientation of the work reveals the problematic issues of the reflection of goodwill in the accounting system.

\section{Subject and object of research}

The subject of the study is the theoretical and methodological principles and practical approaches to the reflection of goodwill and their impact on the completeness and objectivity of information in the financial statements of the enterprise. The subject of the study is the economic nature of goodwill as a component of the value of capital (business/modern companies) and the accounting object of their economic resources.

\section{Methodological approach}

General scientific and special methods were used in the research process to perform the set tasks. The method of theoretical generalization was used to substantiate the essential characteristics of goodwill (acquired and created by the enterprise); systematization - to generalize approaches to its reflection in accounting and reporting; abstractlogical - in the process of identifying the features of goodwill accounting in different national systems of accounting standardization. The research is aimed at revealing the existing problems in the reflection in the accounting system of goodwill as an economic resource of intangible type, analysis of the evolution of theoretical accounting approaches, methods and principles of its cost verification for reflection in practical accounting and reporting. The following methods were used to provide scientific knowledge: empirical (modern practice and evolutionary experience of reflecting these objects in practical accounting); normative-legal interaction of regulatory requirements (standardization) and theoretical developments in the field of improving accounting knowledge for the formation of information about goodwill as a component of the value of enterprise capital: a fundamental approach to the essence of goodwill as an object of accounting system components (business reputation, internally generated and acquired goodwill, intangible capital, etc.).

\section{Presentation of the main research material}

Accounting is always under the influence of financial and economic doctrines that change over time, and therefore during the evolution of this system, a different definitions and concepts were adopted. In the vast majority of economic theories and accounting conventions, the content of the category "goodwill" was reduced to the fact that it organically combined all the assets of an intangible nature that are available at the enterprise. At different stages of economic interpretation in relation to this object of accounting the terms were used "intangible assets", "intangible capital", "goodwill", and later - "information and intellectual assets", "intellectual capital" and others.

The improvement of accounting in the processes of its evolution in relation to the acquired and internally generated goodwill of the enterprise was carried out on the basis of such objects as a trademark, brand, business reputation, etc. At the same time, the prevailing position of scientists was that both goodwill and various intangible assets are the values of fixed assets and represent the real value of the capital of the enterprise. In accounting historiography on the subject under study, it is believed that the oldest established concept of goodwill is given in the "A Counting House Dictionary" in 1883 [7]. It defines goodwill as the 
advantage associated with a good reputation in business. Goodwill is said to be valuable because the business acquired at an "inflated" price is expected to bring in excess profits. Later goodwill is associated with its component (brand names, patents, trademarks, copyrights).

In the period of the formation of theoretical and scientific principles of accounting in it with varying degrees of specification, the category of "intangible assets" contained four types of assets: goodwill, patents, trademarks and copyrights, which were combined on the basis of lack of material form. The intellectual capital market formed during this period required formalized information, that is the need to reflect intangible assets in the company's financial statements. This has led to increased attention of scientists to develop satisfied methods for the accounting system.

In accounting historiography, L. R. Dicksee is recognized as a well-known scholar in the field of accounting for intangible assets. It is believed that the article (lecture) "Goodwill and its Treatment in Accounts" published by him in the economic journal The Accountant in 1897 [8] and the manual published in 1906 laid down certain basic provisions for the definition of this accounting object [9]. According to this scholar, "goodwill as an asset includes the benefits that a business owner receives where the value of the business depends on business relationships goodwill received in the acquisition of a business consists of the right to use those relationships". In other words, the elements of business relations were emphasized in these works - clients will continue to increase cooperation with the company. In his works, the author from a problematic point of view considered the method of estimating goodwill and the order of its reflection on the accounts.

Among the scholars who studied the problem of goodwill accounting was a practicing accountant and the founder of the London firm of chartered accountants Leake P. D. In 1914 he published an article "Goodwill, its nature and evaluation" and in 1921 published a book "Commercial goodwill: its history, value and treatment in accounts" [10].

Goodwill was seen as a collection of intangible assets: patent law, copyright and the right to conduct business, taking into account the use of brand names and trademarks. It was believed that the total working energy of these assets provides additional income in the future. In his proposed principles of construction of the valuation methodology, a postulate was put forward - the current market value of the business is associated with the criterion of future (expected) benefit. In this work was formulated "Super-profit Valuation Theory of Goodwill", according to which goodwill was considered as a right formed on the basis of past resources spent for the expected profit (increase in the value of the company). The value of goodwill in this sense depends on the probability of earning future profits. The described theory became, in fact, the basis for the formation of a profitable method of estimating goodwill.

Another scholar who studied the problems of goodwill accounting was Hatfield H. R., who in his work "Modern Accounting, its principles and some of its problems" [11] argued the impossibility of objectively assessing goodwill and took the position that in the financial statements of this object should be reflected subject to its purchase for the amount paid. Many scholars have criticized the approach to goodwill valuation based on expected super profits, one of which was Kaner $\mathrm{H}$. A. His "New Theory of Goodwill" [12] stated that super profit is a variable and the theory of goodwill valuation based on it is incorrect. These arguments have given a new impetus to the study of accounting for intangible assets.

In 1944, the Accounting Procedures Committee of the American Institute of Accountants issued the world's first normative document - Accounting Research Bulletin No. -24 "Accounting for Intangible Assets" [13]. It substantiates the nature of intangible assets and discloses the rules relating to the recognition, measurement and order of their accounting. The defining feature of this document was the division of all intangible assets into objects with a certain useful life (patents, copyrights, licenses, franchises) and objects with an indefinite term (trademarks, trade secrets, perpetual franchises, subscriptions and organizational costs). For both types of intangible assets, a cost estimate was used. Various approaches to improving the accounting of intangible assets or goodwill have been proposed, including in the accounting developments of East Galician accountants of the past [14]. 
In accordance with international and domestic accounting standards, goodwill refers to intangible assets. However, this object differs in its features from the "traditional" intangible assets (for example, trademarks that still have a graphic image, or a license - documented, know-how confirmed by technical documentation). All intangible assets are reflected in the accounting by the amount of acquisition, or, at the same time, the value measure of goodwill is quite conditional.

International Financial Reporting Standard No. 38 "Intangible Assets" and other standards specify that goodwill is not recognized as an asset because it is not an identified resource that cannot be measured reliably. In the reports of some British companies there is an article "Business reputation", which is affixed a symbolic amount of $1 \$$, that is confirmation that the company has a reputation that can't be expressed in value. At present, there are trends of revaluation of goodwill in current accounting. For example, the US adopted a new accounting standard FAS "Accounting for goodwill and intangible assets", the provisions of which abolish depreciation and regulate the annual analysis and revaluation of goodwill with the writeoff of part of its value at the expense of the company.

Despite the initial number of studies of goodwill, there is still no single interpretation of this concept. There are several approaches to understanding it - for example, economic and accounting. Under both approaches, goodwill is treated as an intangible asset, but under the first one it may arise in the course of the entity's current operations as a set of identified assets from which the company will receive certain economic benefits in the future. Such goodwill is also called internal.

According to the accounting approach, unlike the previous one, goodwill is recognized only at the time of merger (or acquisition) of enterprises. The assertions of international financial reporting standards and Ukrainian national accounting standards are based on the second approach (table 1), as they are based on the condition of business combination.

Table 1

The content of goodwill in accordance with accounting regulations

\begin{tabular}{|l|l|}
\hline \multicolumn{1}{|c|}{ Name of the standard } & \multicolumn{1}{c|}{ The content of goodwill } \\
\hline IFRS 3 "Business combinations" & $\begin{array}{l}\text { Goodwill is an asset representing the future economic benefits arising from } \\
\text { other assets acquired in a business combination that are not individually } \\
\text { identified and separately recognized [15]. }\end{array}$ \\
\hline $\begin{array}{l}\text { Ukrainian Accounting standard 19 } \\
\text { "Association of enterprises" }\end{array}$ & $\begin{array}{l}\text { Goodwill is the excess of the cost of acquisition over the buyer's interest in } \\
\text { the fair value of the identified assets, liabilities and contingent liabilities } \\
\text { received at the acquisition date. }\end{array}$ \\
\hline The tax code of Ukraine & $\begin{array}{l}\text { Goodwill is an intangible asset the value of which is defined as the } \\
\text { difference between the market price and the book value of the assets of the } \\
\text { enterprise as a whole property complex, resulting from the use of better } \\
\text { management, dominant position in the market of goods, services, new } \\
\text { technologies, etc. }\end{array}$ \\
\hline
\end{tabular}

Within each approach, goodwill is treated as a way of measuring a company's value. The authors focus on various aspects: future economic benefits, intangible benefits, and so on. Summarizing the above definitions, goodwill can be interpreted as a specific intangible asset of the enterprise, the value of its business reputation, which is formed under the influence of certain factors, which in the process of purchase and sale allows the company to gain additional benefits or losses.
The above statements show an important feature of goodwill - it cannot be separated from the company, it cannot be sold without the implementation of the entire business. Accordingly, without being the object of sale, goodwill has no price.Just as there is no single interpretation of goodwill, there is no generally accepted classification of the factors that determine it.

Typically, such factors include: reputation, trademarks, patents of the company, its customer 
base, inventions, business model, well-established process of production of goods or services, and so on. Obviously, different scientists have their own assumptions about the components of goodwill. For example, Kevin Prall, Technical Director in the Valuation and Business Analytics practice of BDO, identifies 4 components of goodwill [16].

The first component, reputation, is to some extent recognized among intangible assets in the form of a trademark, but it is impossible to tie all the prestige of the company, the loyalty of its customers, which is also part of reputation, so these elements are partially included in goodwill. Under the infrastructure, the author describes the company's capabilities to create "future technologies", because they are created from existing assets - labor, know-how, basic technology, etc. and will be able to bring excess profits over the life of identified technological assets.

The company's workforce is often underestimated. It does not mean specific individuals, but their knowledge and experience, which will allow the company to continue its activities after its acquisition or merger without the need to train new staff. Workforce cannot be identified as an asset that should be recognized separately from goodwill, therefore, in accordance with international standards, any value allocated to it belongs to the category of goodwill. The synergy of all these elements, the fact that all elements of the business are physically and functionally assembled creates a specific intangible value for the company.

According to the American scientist Robert F. Reilly, the factors that influence goodwill are combined into three components [17]:

1. The company has assets ready for use. Like K. Prall, the scientist pays special attention to the synergy of assets.

2. The presence of excess profits. This element can't be distributed among specific fixed assets of the enterprise. It is best seen in comparison if a competitor had the same tangible and intangible assets as our company, it would not guarantee him a profit of the same level.

3. Expectations of future events that are not related to current operations of the enterprise. Goodwill may arise from future investments, mergers and acquisitions, customer transactions and future services and products invented.

Determining the value of goodwill is not an easy task, as it is influenced by a significant number of factors, several of which are summarized in Table 2.

Factors affecting the value of goodwill

Table 2

\begin{tabular}{|l|l|}
\hline \multicolumn{1}{|c|}{ Factors } & \multicolumn{1}{c|}{ Characteristic } \\
\hline Location of the company & $\begin{array}{l}\text { Favorable location of the company allows you to attract more customers, which leads } \\
\text { to increased turnover and increased value of goodwill }\end{array}$ \\
\hline Management skills & $\begin{array}{l}\text { Thanks to effective management - the established process of production, distribution } \\
\text { of production, profits of the company increase that positively influences goodwill }\end{array}$ \\
\hline Time factor & $\begin{array}{l}\text { A company that has been operating in the market for years or even decades, } \\
\text { compared to a new company that has the same strengths, will have more trust from } \\
\text { customers, a better reputation }\end{array}$ \\
\hline The nature of the business & $\begin{array}{l}\text { A company that manufactures or sells high-quality products, has a stable demand for } \\
\text { its products, favorable government regulation, easy access to raw materials, can } \\
\text { make higher profits, and therefore have a higher cost of goodwill }\end{array}$ \\
\hline Reputation of the owner & $\begin{array}{l}\text { An owner who has a good personal reputation in the market attracts more customers } \\
\text { to his business }\end{array}$ \\
\hline Profitability & $\begin{array}{l}\text { This factor is one of the most important, because fluctuations in the company's } \\
\text { profitability can negatively affect the value of goodwill. At the same time, the } \\
\text { upward trend in profits will lead to an increase in goodwill }\end{array}$ \\
\hline
\end{tabular}

There are also many approaches to valuing goodwill. The following can be called basic:

1. Accounting approach. Under this approach, goodwill is calculated as the difference between the amount paid (or the value of assets transferred) for the company and the value of its identified assets.

This approach is provided by national and international regulations [15]. However, this does 
not mean that this approach has no drawbacks. There are problems with taking into account such goodwill after the merger - you need to confirm the fact that goodwill, which appeared on the balance sheet, really benefits as additional income or otherwise. Another disadvantage is that the structure and purpose of the components of goodwill are clear only to accountants, financiers, top managers, and for other stakeholders such things remain to be unknown.

2. "Excess" approach. According to this approach, goodwill allows the company to generate additional ("Excess") profits. That is why the value of goodwill in this case is equal to the amount of excess profits, cash or other benefits received.

3. Value approach. Under this approach, goodwill is measured by determining the fair value of the replacement of its components.

There are a dozen specific evaluation methods for each approach. The most common in foreign sources are such as: the method of average profit, the method of excess profit and the method of capitalization. Let's take a closer look at each of them.

The method of average profit. According to this method, goodwill is estimated on the basis of the average profit for the agreed number of years. When using this method, you need to subtract the non-operating profit and, accordingly, add the nonoperating loss of the enterprise. The formulas used in this method is shown in Fig. 1.

Average profit $=$ The amount of profit for the agreed number of years / Number of years

Goodwill value $=$ Average profit $*$ Number of years purchase

Fig. 1. Formulas for determining the value of goodwill by the method of average profit

Method of super profit. This method refers to the part of the profit that the company receives in excess of its normal profit. The formulas shown in Fig. 2 are used for calculations.

Capitalization method. With this method, goodwill can be calculated through the capitalization of normal profit or super profit.

The capitalization of normal profits means follows: the average profit is determined, then, based on the rate of return, the cost of capital needed to make a profit of this level is calculated. This part of capital is called the capitalized value of average income.

Normal profit $=$ Capital Employed $*$ Normal rate of return/100

Super profit $=$ Actual profit - normal profit

Goodwill value $=$ Super profit $*$ Number of years purchase

Fig. 2. Formulas for determining the value of goodwill by the method of super profit

During the capitalization of the super profit, the super profit and the capital required to receive such profit are calculated.

Formulas for both types of capitalization method are shown in Fig. 3.

I. Capitalization of average profit
Capitalized value of average profit $=$ Average profit *
$(100 /$ Normal rate of return $)$
Capital Employed $=$ Total assets - liabilities
Goodwill value $=$ Capitalized value of average profit-
Capital Employed
II. Capitalization of super profit
Goodwill value $=$ Super profit $*(100 /$ Normal rate
of return $)$

Fig. 3. Formulas for determining the value of goodwill by capitalization methods

In some situations, goodwill may be negative. Such goodwill arises when the total value of a company is less than the net book value of its assets and liabilities, and when reliable forecasts indicate that the company will have economic losses or upheavals in its operations after the acquisition, which current managers cannot cope. Negative goodwill or badwill, as it is also called, is not defined in either the international financial reporting standards or the Ukrainian national accounting standards, but it is stated that its value is written off with the simultaneous adjustment of retained earnings.

In different countries, approaches to assessing goodwill are different (Table 3). In most countries, positive goodwill is written off or depreciated, negative goodwill is not reflected.

It should be noted that according to the source, there are two types of goodwill - acquired 


\section{O. Lemishovska, I. Mazur}

and inherent (internal). From the name it is clear that the first type occurs during the acquisition of a company. This type of goodwill is reflected in the financial statements. Internal goodwill is created throughout the company's operations, so it is virtually impossible to identify or separate from other company assets. Internally generated goodwill is not recognized as an intangible asset in the financial accounting system, and most users, especially investors, still value it, as its presence creates a synergistic effect and affects other assets to generate greater profits.

The existence of unrecognized in the accounting system of the enterprise internally generated goodwill indicates the advantages of the enterprise and its better position in the market. Acquired and internally generated goodwill differ not only in reflection in the financial statements, but also in other features, as shown in Fig. 4.

Table 3

\section{Features of goodwill assessment in different countries}

\begin{tabular}{|l|l|}
\hline \multicolumn{1}{|c|}{ Country } & \multicolumn{1}{c|}{ Features of goodwill assessment } \\
\hline Germany & $\begin{array}{l}\text { Goodwill is the difference between the market value of the assets acquired and the investment cost. } \\
\text { It can be written off when purchased on reserve, or depreciated (in practice, consider a period of } 40 \\
\text { years). }\end{array}$ \\
\hline France & $\begin{array}{l}\text { Goodwill is an intangible asset that is not reported. There are no restrictions on the depreciation } \\
\text { period. }\end{array}$ \\
\hline $\begin{array}{l}\text { Great } \\
\text { Britain, } \\
\text { Ireland }\end{array}$ & $\begin{array}{l}\text { The difference between the cost of acquisition and the cost of its individual components. Positive } \\
\text { goodwill is calculated through write-offs or depreciation. }\end{array}$ \\
\hline Spain & $\begin{array}{l}\text { When the acquisition price of a company exceeds the net book value of the acquired assets, they } \\
\text { can be increased to their market value. The balance should be depreciated over 10 years. }\end{array}$ \\
\hline Sweden & $\begin{array}{l}\text { Goodwill is accounted as fixed capital, 10 \% of which must be depreciated at least annually (over } \\
10 \text { years). }\end{array}$ \\
\hline Belgium & $\begin{array}{l}\text { It is calculated as the difference between the price paid for the company and the book value of its } \\
\text { net assets. Depreciated not more than 5 years; negative goodwill is not reflected. }\end{array}$ \\
\hline Estonia & $\begin{array}{l}\text { Goodwill on the acquisition of a business unit represents the difference between the purchase price } \\
\text { and the real value of the net assets. Positive goodwill is depreciated over 5 years. Negative } \\
\text { goodwill is not reflected. }\end{array}$ \\
\hline
\end{tabular}

Internally generated

\section{It is created inside the enterprise for a long time}
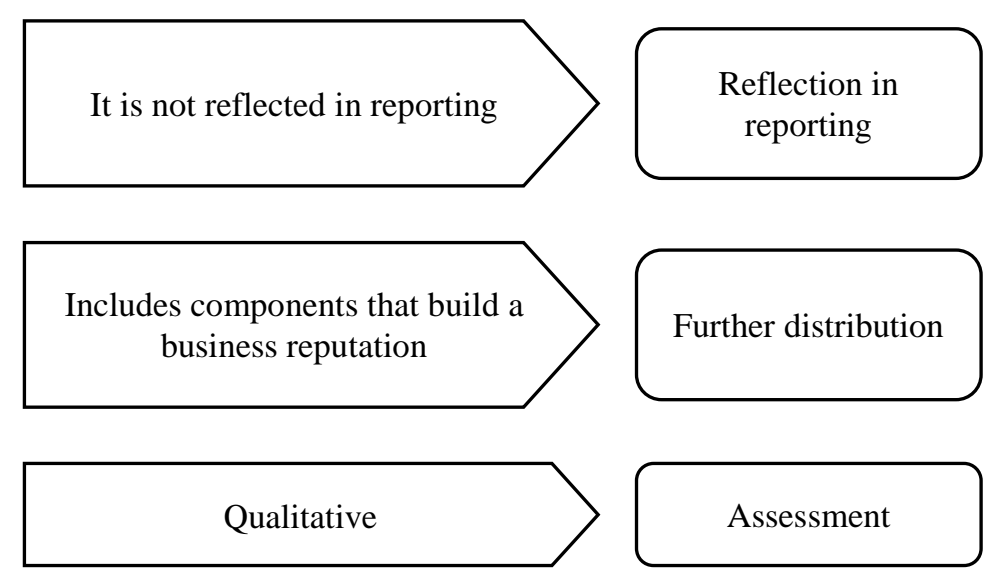

Divided into positive and negative (badwill)

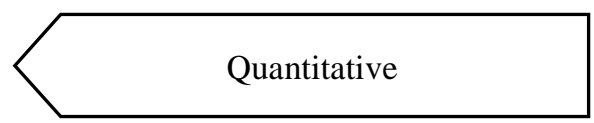

Fig. 4. Features that distinguish acquired goodwill from internal 
The analysis of world practice shows the following possible approaches to the reflection of goodwill as an asset in the accounting system:

1. Capitalization of goodwill. The approach involves capitalizing goodwill with or without depreciation. In modern accounting practice, the first option is the most common. In this case, the company must use a certain method of depreciation of goodwill, which primarily depends on the depreciation period. If the activities of the acquire are projected to be impaired in the future, the cost of negative goodwill is recognized as income on a straight-line basis over the period in which the loss occurs. Under the second option, goodwill is accounted for as a non-depreciable asset, but this does not mean that the goodwill valuation is preserved forever. Periodic testing of goodwill for impairment is possible.

2. Fixing goodwill in the account with the subsequent write-off at the expense of various sources. Under the approach, goodwill is not recognized as an asset and its acquisition costs are written off against certain sources, in particular:

1) in international practice, the option of one-time write-off of goodwill by reducing the capital of owners is used. Today in Ukraine it is effective for goodwill in corporatization.

2) in some cases it is possible to write off one-time goodwill as part of the expenses of the reporting period or other components of equity. The current legislation does not regulate the procedure for such write-offs.

The main problem of goodwill accounting in Ukraine can be called non-reflection in the accounting of components of internal goodwill (there is reflection of acquired only). At present, the value of goodwill is reflected in the Goodwill account in accordance with the chart of accounts, but its analytical accounts do not reflect the business reputation, image, business relationships, customer base and other components of internal goodwill. The debit of the Goodwill account reflects the positive goodwill on the acquisition, on credit, its write-off (in correspondence with the withdrawn capital account and loss from impairment) (in correspondence with the expense account). So there is also the problem with financial statements, because internal goodwill is not reflected in it.
Once goodwill is recognized as an asset, it is subject to a systematic impairment test. According to ASU-2021-03, such testing should be performed if events have occurred that could affect the fair value of the entity. IAS 36 "Impairment of Assets" describes examples of significant adverse effects, including changes in the economic or market environment in which the company operates and the situation where the carrying amount of the company's net assets is greater than its market capitalization.

Covid-19 has caused a significant deterioration in economic conditions for many companies, such as tourism, construction, trade, education, etc., so the test for impairment of assets, including goodwill, must be conducted.

\section{Conclusions and prospects of further research}

Based on the developed theoretical and legal sources, it can be concluded that the existence of goodwill is objective in nature, and this allows us to assert the need to reflect in the accounting system both acquired and created by the enterprise goodwill. Today, the significance of this category is the regulation of the establishment of an objective expression of the capital of the enterprise and the value of the business. The main problem with goodwill remains its ambiguity, the lack of universal approaches to its definition, as well as the lack of research on internal goodwill and its nonreflection in the financial statements.

The acquisition of goodwill is usually made at the expense of the equity of the purchasing entity, and therefore the write-off of the value of goodwill from impairment should be made at the expense of capital, and not attributed to costs. A possible option is to write off the lost business reputation at the expense of "reserve capital".

This becomes especially evident in crisis situations within the national or global economy. In order to create such a target reserve capital, it is necessary to include it in the international standard "Business combinations" at the state level. To reflect the lost (written off) value of goodwill, it is proposed to open a counter-passive item (including a counter-passive account) in the "Equity" section of the balance sheet liability, which will allow to interpret changes in the company's position in capital and investment markets. 


\section{O. Lemishovska, I. Mazur}

\section{References}

1. IFRS 13 "Fair Value Measurement". Access mode: https://www.ifrs.org/issued-standards/list-ofstandards/ifrs-13-fair-value-measurement/

2. Baruch L. (2018). The deterioration usefulness of financial report information and how to reverse it. Accounting and Business Research (48), P. 465493

3. Kucher S. V., Zakharov D. M. (2017). The history of development of goodwill as an accounting category and the main approaches to its definition. Economy and Society (Vip. 9), P. 1162-1166

4. Interconnected standard setting for corporate reporting, (2019). Accountancy Europe's thoughtleadership series. Brussels: Accountancy Europe, $28 p$

5. Marr B. (2007). Measuring and managing intangible value drivers. Business Strategy Series (Vol. 8, No. 3), P. $172-178$

6. Nazarenko I. M. (2015). Development of the category "capital": historical discourse from the standpoint of accounting. Scientific Bulletin of Kherson State University. Series: Economic Sciences (Vip. 11), P. 134-140

7. Courtis J. K. (1983). Business Goodwill: Conceptual Clarification via Accounting, Legal and Etymological Perspectives. The Accounting Historians Journal (Vol. 10, No. 2), P. 1-38.

8. Dicksee L. (1897). Goodwill and its Treatment in Accounts. The Accountant (Vol. 23, No. 115)

9. Dicksee L. Tillyard F. (1906). Goodwill, Gee and Co. Printers and Publishers, Trind Edition. 33 p.

10. Leake P. D. (1921). Commercial goodwill: its History. Value and treatment in Accounts. London: Gee. 201 p.
11. Hatfield H. R. (1909). Modern Accounting, its principles and some of its problems. New York: D. Appleton.367p.

12. Kaner H. A. (1937). New Theory of Goodwill. London: Sir I. Pitman \& Sons Ltd. Access mode: http//trove.nla.gov.au/work/13517505? q \& version $l d=16028315$.

13. Accounting Research Bulletin "Accounting for Intangible Assets" (1944). American Institute of Accountants. (24), P. 195-201

14. Lemishovska O. (2020). Intangible values in the accounting theoretical and applied sphere of the Eastern Galicia of the second half of XIX - the beginning of $X X$ century: historical discourse. Economics, Entrepreneurship, Management (Vol 7. No2), $P$ 78-90

15. IFRS 3 Business Combinations. Access mode https://www.ifrs.org/issued-standards/list-ofstandards/ifrs-3-business-combinations/

16. Is Goodwill a Wasting Asset? IVSC Perspectives Paper. Access mode: https://www.ivsc.org/news/ article/is-goodwill-a-wasting-asset

17. Goodwill Valuation Approaches, Methods, and Procedures. Financial Advisory Services Insights Access mode: https://pdf4pro.com/view/goodwillvaluation-approaches-methods-and-procedures47b4le.html

18. Steven L. Henning Valuation of the Components of Purchased Goodwill / Steven L. Henning, Barry L. Lewis, Wayne H. Shaw // Journal of Accounting Research. 2000. No. 2. - P. 375-386.

19. Accounting Procedure for Valuation of Goodwill [Electronic resource]. - Access mode https://www.yourarticlelibrary.com/accounting/goo dwill/accounting-procedure-for-valuation-ofgoodwill-4-methods/57243 